JRPB, Vol. 7, No. 1, Maret 2019, Hal. 85 - 94

DOI: $10.29303 /$ jrpb.v7i1.91

ISSN 2301-8119, e-ISSN 2443-1354

http://jrpb.unram.ac.id/

\title{
OPTIMASI SUHU DAN WAKTU PENGEPRESAN DALAM PEMBUATAN BUBUK KAKAO PADA SKALA KELOMPOK TANI
}

\author{
Optimization of Temperature and Time Extraction for Cocoa Powder Production \\ on Small Scale Farmers
}

\section{Satria Bhirawa Anoraga ${ }^{1, *)}$, Sri Wijanarti' ${ }^{1}$ Iman Sabarisman', Anjar Ruspita Sari ${ }^{1}$ \\ ${ }^{1}$ Program Studi Agroindustri, Departemen Teknologi Hayati dan Veteriner, Sekolah Vokasi Universitas Gadjah Mada, Jl. Yacaranda, Sekip, Yogyakarta}

\author{
Email*): satriabhirawa@ugm.ac.id \\ Diterima: November 2018 \\ Disetujui: Maret 2019
}

\begin{abstract}
Mechanical pressure system was a process to extract cocoa liquor for cocoa powder production. The objective of this study was to determine the optimum extraction time and temperature to obtain cocoa powder which accord to standard. Observed parameter were moisture content, fat content, color and sensory test. Optimization was applied using 2 factors, i.e. $X_{1}$ (time, minute) and $X_{2}$ (temperature, ${ }^{\circ} C$ ) with minitab program. The result showed that extraction time and temperature affected the brightness of cocoa powder significantly. The optimum extraction process to get a brightness quality as well as industrial product could be conducted at $70^{\circ} \mathrm{C}$ for 30.114 minutes.
\end{abstract}

Keywords: cocoa powder, liquor, extraction, temperature

\begin{abstract}
ABSTRAK
Pengepresan merupakan proses pemisahan lemak kakao dari pasta hingga batas tertentu dengan menggunakan alat pengepres hidrolis. Penelitian ini bertujuan untuk menentukan suhu dan waktu pengepresan yang optimal untuk memperoleh bubuk kakao yang standar. Parameter yang diamati adalah rendemen, kadar air, kadar lemak dan warna (kecerahan) bubuk kakao. Optimasi dilakukan dengan dua faktor, waktu $\left(\mathrm{X}_{1}\right)$ dan suhu $\left(\mathrm{X}_{2}\right)$ menggunakan minitab. Hasil optimasi menunjukkan suhu dan lama pengepresan mempengaruhi kecerahan warna bubuk kakao secara signifikan, namun tidak berpengaruh terhadap kadar air, kadar lemak, dan rendemen. Pengepresan paling optimal dilakukan pada suhu $70^{\circ} \mathrm{C}$ dengan waktu waktu 30,114 menit untuk memperoleh kecerahan warna bubuk kakao yang beredar di pasaran.
\end{abstract}

Kata kunci: bubuk kakao, pasta, pengepresan, suhu 


\section{PENDAHULUAN}

\section{Latar Belakang}

Bubuk merupakan salah satu produk turunan kakao yang diperoleh dari bungkil kakao hasil pengepresan dan telah diubah bentuknya menjadi bubuk. Standar mutu bubuk kakao telah diatur dalam SNI 3747:2009, dengan parameter uji antara lain kadar air, kadar lemak, kehalusan, bau, rasa dan warna (SNI, 2009). Dalam rangka meningkatkan mutu bubuk kakao, Pemerintah Republik Indonesia telah mewajibkan pemberlakuan ketentuan Standar Nasional Indonesia (SNI) terhadap produk kakao bubuk sejak tahun 2009. Kebijakan tersebut diatur dalam Peraturan Menteri Perindustrian Nomor 45/MIND/PER/5/2009 tentang Pemberlakuan Standar Nasional Indonesia (SNI) Kakao Bubuk Secara Wajib.

Pada umumnya alat pengepres yang digunakan untuk proses ekstraksi lemak kakao adalah pengepres tipe mekanis. Alat ini dinilai lebih ekonomis dan lebih sesuai dengan kondisi UKM di Indonesia, terutama terkait biaya investasi yang rendah, kemudahan operasional dan perawatan (Mulato, dkk., 2004). Lemak kakao dikeluarkan dari biji yang telah dipastakan dengan cara dikempa atau diberi tekanan (Mulato, dkk., 2008). Namun, menurut Indarti (2007), rendemen hasil pengepresan tidak begitu dipengaruhi oleh tekanan, tapi lebih dipengaruhi oleh faktor suhu. Dari rentang suhu $60-90^{\circ} \mathrm{C}$, diperoleh rendemen paling tinggi pada suhu $70^{\circ} \mathrm{C}$. Sehingga pada penelitian kali ini tidak dilakukan variasi pada tekanan. Salah satu parameter yang sangat dipengaruhi oleh suhu saat pengepresan adalah kadar air, dimana semakin tinggi suhu yang digunakan maka kadar air bubuk kakao akan semakin kecil (Junaidi, dkk., 2008). Hasil lemak kakao maksimal diperoleh dalam waktu 10-15 menit untuk satu kali pengepresan, dengan kapasitas $0,5 \mathrm{~kg}$ per batch. Rendemen hasil pengepresan sangat dipengaruhi oleh faktor suhu, kadar air biji, ukuran partikel dan waktu pengepresan (Manulu, dkk., 2017).
Beberapa pengamatan mengenai proses optimasi pada pengolahan kakao telah dilakukan. Misnawi, dkk., (2005) melakukan pengamatan tentang optimasi suhu dan lama penyangraian biji kakao menggunakan penyangrai skala kecil tipe silinder. Hasil yang diperoleh menunjukkan bahwa suhu dan lama penyangraian berpengaruh secara interaktif terhadap bilangan peroksida lemak kakao dan warna serta sifat organoleptik bubuk kakao yang dihasilkan. Kondisi optimum penyangraian dicapai pada suhu $140^{\circ} \mathrm{C}$ dengan lama 20 menit. Sedangkan dari segi penerimaan dan karakteristik sensori, suhu penyangraian lebih berpengaruh daripada waktu penyangraian, dengan suhu optimum penyangraian yang dapat diterima konsumen (penampilan, aroma, rasa, tekstur dan atribut kualitas keseluruhan) berkisar antara 90$110^{\circ} \mathrm{C}$ (Rocha, et al., 2017). Widya (2016) melakukan proses optimasi ekstraksi pektin dari kulit kakao menggunakan RSM, dan diperoleh hasil optimum yaitu $85^{\circ} \mathrm{C}$ untuk suhu, 3,27 untuk pH dan 120 menit untuk lama ekstraksi. Permana, dkk., (2012) melakukan optimasi Isolasi Lipase Indigenous Biji Kakao, dimana hasil penelitian menunjukkan bahwa lipase berada dalam sitosol dan penghilangan lemak tidak meningkatkan aktivitas lipase. Aidoo, dkk., (2014) mengamati kondisi optimum campuran inulin dan polydextrose sebagai pengganti sukrosa selama pembuatan cokelat bebas gula, dimana formulasi cokelat yang terdiri dari $75,3594 \%$ polydextrose dan $24,6406 \%$ inulin merupakan konsentrasi optimum yang menghasilkan karakteristik kualitas reologi dan fisik yang paling dapat diterima. Mine, et al., (2016) melakukan optimasi pembuatan dark chocolate dengan RSM untuk melihat pengaruh kondisi pemrosesan pada profil procyanidin dan kapasitas antioksidan cokelat. Berdasarkan data yang diperoleh menunjukkan bahwa proses pembuatan cokelat, khususnya peningkatan derajat alkalisasi dan suhu penyangraian secara signifikan mengurangi fenolik dan kapasitas antioksidan. Priyangini, et al., 
(2018) melakukan optimasi ekstraksi pektin dari sekam kulit biji kakao dengan asam askorbat menggunakan RSM, dimana kondisi ekstraksi optimum pada $\mathrm{pH} 2,5$, suhu $95^{\circ} \mathrm{C}$, dan waktu 45 menit. V.B. Shet, et al., (2018) melakukan optimasi hidrolisis asam dari kulit biji kakao menggunakan RSM untuk produksi etanol, dengan hasil kondisi yang optimum adalah $8,36 \%$ (berat per volume) CPS, 3,6 N konsentrasi $\mathrm{HCl}$ dengan 7,36 jam hidrolisis asam yang menghasilkan gula pereduksi 4,09 g/L. Dari beberapa pengamatan mengenai optimasi pengolahan kakao tersebut belum ada proses optimasi pada proses pengepresan atau ektraksi lemak kakao. Hal ini perlu dilakukan untuk mengetahu kondisi optimum dalam pembuatan bubuk kakau yang sesuai standar.

\section{Tujuan}

Penelitian ini bertujuan untuk menentukan suhu dan waktu pengepresan yang optimal untuk memperoleh bubuk kakao yang standar.

\section{METODE PENELITIAN}

\section{Alat dan Bahan}

Bahan utama yang digunakan adalah biji kakao terfermentasi dari Desa Kakao Banjaroya, Kulonprogo. Alat yang digunakan antara lain: alat sangrai kapasitas $5 \mathrm{~kg}$ tipe batch, alat pemasta tipe ulir kapasitas $5 \mathrm{~kg}$, alat pengepres mekanis kapasitas $5 \mathrm{~kg}$, timbangan analitik Fujitsu FS- AR210 Japan, oven Memmert UN 55 Germany, soxhlet iwaki Thailand, erlenmeyer iwaki Thailand, refractometer Atago Japan, dan peralatan pendukung lainnya seperti kertas saring, kain, nampan, dan gelas ukur. Penelitian dilakukan pada bulan Juni-Juli 2018 di Pusat Inkubasi Pengolahan Kakao, Program Studi Agroindustri, Sekolah Vokasi Universitas Gadjah Mada.

\section{Metode}

Biji kakao disangrai selama 10-15 menit pada suhu $100^{\circ} \mathrm{C}$ hingga berubah warna dan muncul aroma cokelat. Setelah keluar dari penyangrai dan tidak terlalu panas, biji kakao dikupas kulit arinya untuk memperoleh nib kakao. Nib tersebut dipasta dan selanjutnya dilakukan pengepresan. Pasta tersebut dimasukkan kedalam kain saring sebanyak 200 gr, dan dimasukkan dalam alat pengepres. Proses pengepresan menggunakan variasi suhu $70^{\circ} \mathrm{C}, 100^{\circ} \mathrm{C}$, dan $100^{\circ} \mathrm{C}$, dengan variasi waktu lama pengepresan selama 20 menit, 30 menit, 45 menit. Bungkil kakao dari pengepresan dihaluskan dan dilakukan pengukuran kecerahan warna (nilai L*), kadar air, kadar lemak, dan randemen.

\section{Analisis Data}

Data pengujian diolah dengan program microsoft office excel, dan dimasukkan kedalam program minitab 17 untuk dioptimasi. Dari hasil analisis diperoleh persamaan model untuk setiap parameter yang ditentukan dengan melihat besarnya nilai Adj-R square. Nilai $\mathrm{R}^{2}$ digunakan untuk melihat seberapa besar pengaruh kedua faktor tersebut terhadap masing-masing parameter. Tingkat signifikansi untuk masing-masing variabel diuji dengan menggunakan uji $p$ (probability). Jika nilai $\mathrm{p}$ kurang dari 0,05 maka variabel dapat dikatakan berpengaruh secara signifikan terhadap variabel yang lain. Semakin kecil nilai $\mathrm{p}$ maka semakin besar tingkat signifikansinya

\section{HASIL DAN PEMBAHASAN}

\section{Pengaruh Suhu dan Waktu Pengepresan Kakao terhadap Warna (kecerahan) Bubuk Kakao}

Pada pengamatan ini terdapat dua faktor yang dibuat bervariasi untuk dioptimalkan, yaitu suhu $(X)$ dan waktu $\left(X_{2}\right)$. Dari hasil analisis model diperoleh nilai $\mathrm{R}^{2}$ sebesar $95,08 \%$, artinya waktu dan suhu pengepresan memberikan pengaruh sebesar 95,08\% terhadap kecerahan warna bubuk kakao. Model yang disarankan adalah full quadratic dengan nilai Adj-R Square $86,88 \%$, hal ini mengidentifikasikan bahwa 
model matematis memiliki signifikansi yang tinggi dan dapat digunakan (available) untuk memprediksi kecerahan warna bubuk kakao.

Tabel 1 menunjukkan hasil anova dan tabel 2 merupakan tabel koefisien terestimasi untuk kecerahan warna bubuk kakao. Pada tabel 1 dapat dilihat bahwa model memiliki nilai f-value 11,6 dengan nilai p-value 0,035 yang menunjukkan model signifikan. Tabel 1 menunjukkan bahwa waktu pengepresan $\left(X_{l}\right)$ berpengaruh secara signifikan terhadap kecerahan warna bubuk kakao karena nilai p-nya di bawah 0,05 . Namun tingkat suhu $\left(X_{2}\right)$ tidak berpengaruh secara signifikan terhadap kecerahan warna bubuk kakao karena nilai p-nya di atas 0,05. Hubungan kuadratik untuk suhu dan waktu menunjukkan hasil yang tidak signifikan dengan nilai 0,07 , waktu pengepresan $\left(X 1^{2}\right)$ dengan nilai 0,105 , dan suhu pengepresan $\left(X 2^{2}\right)$ dengan nilai 0,361. Sedangkan pada Tabel 2 menunjukkan bahwa pada tabel tersebut terdapat persamaan regresi koefisien terestimasi yaitu dengan nilai awal intercept 49,798.

Setelah dilakukan analisis sidik ragam diperoleh koefisien terestimasi, maka dapat diperoleh persamaan regresi untuk kecerahan warna bubuk kakao:

Kecerahan warna $(\mathrm{Y})=49,798-2,312 \mathrm{X}_{1}+$ $0,541 \mathrm{X}_{2}$

Tabel 1. Anova untuk kecerahan warna bubuk kakao

\begin{tabular}{lccccc}
\hline Source & DF & Adj SS & Adj MS & F-Value & P-Value \\
\hline Model & 5 & 40,6237 & 8,1247 & 11,6 & 0,035 \\
Linear & 2 & 32,4337 & 16,2169 & 23,15 & 0,015 \\
Waktu $\left(\mathrm{X}_{1}\right)$ & 1 & 30,8995 & 30,8995 & 44,11 & 0,007 \\
Suhu $\left(\mathrm{X}_{2}\right)$ & 1 & 1,7453 & 1,7453 & 2,49 & 0,213 \\
Square & 2 & 4,5031 & 2,2516 & 3,21 & 0,179 \\
Waktu*Waktu & 1 & 3,6918 & 3,6918 & 5,27 & 0,105 \\
Suhu*Suhu & 1 & 0,8113 & 0,8113 & 1,16 & 0,361 \\
2-Way Interaction & 1 & 5,3331 & 5,3331 & 7,61 & 0,07 \\
Waktu*Suhu & 1 & 5,3331 & 5,3331 & 7,61 & 0,07 \\
Error & 3 & 2,1016 & 0,7005 & & \\
Total & 8 & 42,7253 & & & \\
\hline
\end{tabular}

Tabel 2. Koefisien regresi terestimasi untuk kecerahan warna bubuk kakao

\begin{tabular}{lcccccc}
\hline Term & Effect & Coef & SE Coef & T-Value & P-Value & VIF \\
\hline Constant & & 49,798 & 0,813 & 61,26 & 0 & \\
Waktu $\left(X_{1}\right)$ & $-4,624$ & $-2,312$ & 0,348 & $-6,64$ & 0,007 & 1,05 \\
Suhu $\left(X_{2}\right)$ & 1,082 & 0,541 & 0,343 & 1,58 & 0,213 & 1,09 \\
Waktu*Waktu & $-2,849$ & $-1,425$ & 0,621 & $-2,3$ & 0,105 & 1,01 \\
Suhu*Suhu & 1,768 & 0,884 & 0,821 & 1,08 & 0,361 & 1,08 \\
Waktu*Suhu & 2,204 & 1,102 & 0,399 & 2,76 & 0,07 & 1,05 \\
\hline
\end{tabular}

Model matematis yang terbentuk dari rancangan percobaan tabel 2 secara umum memiliki tingkat signifikan yang tinggi, artinya model tersebut dapat digunakan untuk memprediksikan berapa besar kecerahan warna bubuk kakao yang terbentuk pada suhu dan waktu pengepresan, karena nilai F-nya sebesar 11,6 dan nilai Pnya 0,035 . Hal ini berarti peluang terjadinya noise (pengaruh faktor pengganggu) pada penelitian tersebut hanya 3,5\%. Model matematis tersebut menunjukkan bahwa 
waktu pengepresan lebih berpengaruh terhadap kecerahahan warna bubuk kakao dibandingkan dengan suhu pengepresan. Hal ini karena nilai $\mathrm{P}$ waktu pengepresan lebih kecil daripada suhu pengepresan.

Meski demikian, secara teoritis perlakuan panas juga masih memberikan pengaruh terhadap kecerahan bubuk kakao. Hal ini disebabkan oleh penurunan kadar air yang cepat sebagai efek adanya panas. Dengan rendahnya kandungan kadar air pada bubuk kakao menyebabkan pergerakan antar reaktan sangat terbatas, sehingga reaksi pencoklatan tidak berlangsung sempurna (Supriyanto dan Marseno, 2010). Hasil yang sama juga diperoleh Hanifah, dkk., (2017) dalam pembuatan bubuk cincau, dimana semakin tinggi suhu yang diberikan mengakibatkan kecerahan bubuk semakin menurun.

\section{Pengaruh Suhu dan Waktu Pengepresan Kakao terhadap Kadar Lemak Bubuk Kakao}

Hasil analisis model diperoleh nilai $\mathrm{R}^{2}$ sebesar $82,21 \%$, artinya waktu dan suhu pengepresan memberikan pengaruh sebesar $82,21 \%$ terhadap kadar lemak bubuk kakao. Model yang disarankan adalah full quadratic dengan nilai Adj-R Square $52,56 \%$, hal ini mengidentifikasikan bahwa model matematis memiliki signifikansi yang cukup rendah untuk dapat digunakan memprediksi kadar lemak bubuk kakao.

Tabel 3 menunjukkan hasil anova dan tabel 4 merupakan tabel koefisien terestimasi untuk kadar lemak bubuk kakao. Pada tabel 3 dapat dilihat bahwa model memiliki nilai $\mathrm{f}$-value 2,77 dengan nilai $\mathrm{p}$ value 0,215 yang menunjukkan model tidak signifikan. Tabel 1 menunjukkan bahwa waktu pengepresan $\left(X_{1}\right)$ tidak berpengaruh signifikan terhadap kadar lemak bubuk kakao karena nilai p-nya diatas 0,05. Tingkat suhu $\left(X_{2}\right)$ juga tidak berpengaruh secara signifikan terhadap kecerahan warna bubuk kakao karena nilai p-nya di atas 0,05. Hubungan kuadratik untuk suhu dan waktu menunjukkan hasil yang tidak signifikan yaitu waktu dan suhu $\left(X_{1} * X_{2}\right)$ dengan nilai 0,194 , waktu pengepresan $\left(X_{1}^{2}\right)$ dengan nilai 0,153 , dan suhu pengepresan $\left(X_{2}^{2}\right)$ dengan nilai 0,605. Sedangkan pada tabel 4 menunjukkan bahwa pada tabel tersebut terdapat persamaan regresi koefisien terestimasi yaitu dengan nilai awal intercept 40,38 .

Setelah dilakukan analisis sidik ragam diperoleh koefisien terestimasi, maka dapat diperoleh persamaan regresi untuk kadar lemak bubuk kakao::

$\operatorname{Kadar} \operatorname{lemak}(\mathrm{Y})=40,38+1,052 \mathrm{X}_{1}+$ $0,916 X_{2}$

Tabel 3. Anova untuk kadar lemak bubuk kakao

\begin{tabular}{lccccc}
\hline Source & DF & Adj SS & Adj MS & F-Value & P-Value \\
\hline Model & 5 & 29,358 & 5,8716 & 2,77 & 0,215 \\
Linear & 2 & 11,5749 & 5,7874 & 2,73 & 0,211 \\
Waktu $\left(\mathrm{X}_{1}\right)$ & 1 & 6,3955 & 6,3955 & 3,02 & 0,181 \\
Suhu $\left(\mathrm{X}_{2}\right)$ & 1 & 5,0086 & 5,0086 & 2,37 & 0,222 \\
Square & 2 & 8,3704 & 4,1852 & 1,98 & 0,283 \\
Waktu*Waktu & 1 & 7,6674 & 7,6674 & 3,62 & 0,153 \\
Suhu*Suhu & 1 & 0,703 & 0,703 & 0,33 & 0,605 \\
2-Way Interaction & 1 & 5,8978 & 5,8978 & 2,78 & 0,194 \\
Waktu*Suhu $\left(\mathrm{X}_{1} \mathrm{X}_{2}\right)$ & 1 & 5,8978 & 5,8978 & 2,78 & 0,194 \\
Error & 3 & 6,3534 & 2,1178 & & \\
Total & 8 & 35,7114 & & & \\
\hline
\end{tabular}


Tabel 4. Koefisien regresi terestimasi untuk kadar lemak bubuk kakao

\begin{tabular}{lcccccc}
\hline Term & Effect & Coef & SE Coef & T-Value & P-Value & VIF \\
\hline Constant & & 40,38 & 1,41 & 28,57 & 0 & \\
Waktu $\left(\mathrm{X}_{1}\right)$ & 2,104 & 1,052 & 0,605 & 1,74 & 0,181 & 1,05 \\
Suhu $\left(\mathrm{X}_{2}\right)$ & 1,833 & 0,916 & 0,596 & 1,54 & 0,222 & 1,09 \\
Waktu*Waktu & 4,11 & 2,05 & 1,08 & 1,9 & 0,153 & 1,01 \\
Suhu*Suhu & 1,65 & 0,82 & 1,43 & 0,58 & 0,605 & 1,08 \\
Waktu*Suhu & 2,318 & 1,159 & 0,694 & 1,67 & 0,194 & 1,05 \\
\hline
\end{tabular}

Bubuk kakao yang dihasilkan dari beberapa perlakuan pengepresan ini masih memiliki kadar lemak yang tinggi. Kandungan lemak tersebut masih sangat jauh jika dibandingkan dengan bubuk kakao yang beredar dipasaran, yaitu sekitar 1022\% (Mulato, dkk., 2005). Proses pengepresan menggunakan alat pengempa hidrolis memang menghasilkan bubuk kakao dengan kandungan lemak yang tinggi. Oleh karena itu dibutuhkan alat pengepres dengan tekanan diatas $40 \mathrm{MPa}$ untuk mengeluarkan lemak agar sesuai dengan standar yang ada dipasaran. Selain itu, untuk mengurangi kadar lemak yang belum mampu dikeluarkan oleh alat pengepres, dapat juga dilakukan ekstraksi lemak kakao menggunakan pelarut. Salah satu yang biasa digunakan adalah pelarut heksan, yang mampu menurunkan kandungan lemak bubuk kakao sebesar 28\% (Widayat, 2013).

\section{Pengaruh Suhu dan Waktu Pengepresan Kakao terhadap Kadar Air Bubuk Kakao}

Hasil analisis model diperoleh nilai $\mathrm{R}^{2}$ sebesar 39,68\%, artinya waktu dan suhu pengepresan memberikan pengaruh sebesar 39,68\% terhadap kadar air bubuk kakao. Model memiliki nilai Adj-R Square sangat rendah yang menunjukkan bahwa model matematis memiliki signifikansi yang rendah untuk dapat digunakan memprediksi kadar air bubuk kakao.

Tabel 5 menunjukkan hasil anova dan tabel 6 merupakan tabel koefisien terestimasi untuk kadar air bubuk kakao. Pada tabel 5 dapat dilihat bahwa model memiliki nilai f-value 0,39 dengan nilai $\mathrm{p}$ value 0,829 yang menunjukkan model tidak signifikan. Tabel 5 menunjukkan bahwa waktu pengepresan $\left(X_{l}\right)$ tidak berpengaruh signifikan terhadap kadar air bubuk kakao karena nilai $\mathrm{p}$-nya diatas 0,05 . Tingkat suhu $\left(X_{2}\right)$ juga tidak berpengaruh secara signifikan terhadap kadar air bubuk kakao karena nilai p-nya di atas 0,05 . Hubungan kuadratik untuk suhu dan waktu menunjukkan hasil yang tidak signifikan yaitu waktu dan suhu $\left(X_{1} * X_{2}\right)$ dengan nilai 0,461 , waktu pengepresan $\left(X_{1}^{2}\right)$ dengan nilai 0,514 , dan suhu pengepresan $\left(X_{2}^{2}\right)$ dengan nilai 0,796. Sedangkan pada Tabel 6 menunjukkan bahwa pada tabel tersebut terdapat persamaan regresi koefisien terestimasi yaitu dengan nilai awal intercept 4,78 .

Setelah dilakukan analisis sidik ragam diperoleh koefisien terestimasi, maka dapat diperoleh persamaan regresi untuk kadar air bubuk kakao:

$\operatorname{Kadar} \operatorname{air}(\mathrm{Y})=4,78-0,097 \mathrm{X}_{1}+0,247 \mathrm{X}_{2}$

Tabel 5. Anova untuk kadar air bubuk kakao

\begin{tabular}{lccccc}
\hline Source & DF & Adj SS & Adj MS & F-Value & P-Value \\
\hline Model & 5 & 2,27035 & 0,45407 & 0,39 & 0,829 \\
Linear & 2 & 0,41549 & 0,20775 & 0,18 & 0,843 \\
Waktu $\left(\mathrm{X}_{1}\right)$ & 1 & 0,05477 & 0,05477 & 0,05 & 0,841 \\
Suhu $\left(\mathrm{X}_{2}\right)$ & 1 & 0,36483 & 0,36483 & 0,32 & 0,613 \\
Square & 2 & 0,71874 & 0,35937 & 0,31 & 0,753
\end{tabular}




\begin{tabular}{llllll} 
Waktu*Waktu & 1 & 0,62679 & 0,62679 & 0,54 & 0,514 \\
Suhu*Suhu & 1 & 0,09195 & 0,09195 & 0,08 & 0,796 \\
2-Way Interaction & 1 & 0,81881 & 0,81881 & 0,71 & 0,461 \\
Waktu*Suhu $\left(\mathrm{X}_{1} \mathrm{X}_{2}\right)$ & 1 & 0,81881 & 0,81881 & 0,71 & 0,461 \\
Error & 3 & 3,45112 & 1,15037 & & \\
Total & 8 & 5,72148 & & & \\
\hline
\end{tabular}

Tabel 6. Koefisien regresi terestimasi untuk kadar air bubuk kakao

\begin{tabular}{lcccccc}
\hline Term & Effect & Coef & SE Coef & T-Value & P-Value & VIF \\
\hline Constant & & 4,78 & 1,04 & 4,59 & 0,019 & \\
Waktu $\left(\mathrm{X}_{1}\right)$ & $-0,195$ & $-0,097$ & 0,446 & $-0,22$ & 0,841 & 1,05 \\
Suhu $\left(\mathrm{X}_{2}\right)$ & 0,495 & 0,247 & 0,439 & 0,56 & 0,613 & 1,09 \\
Waktu*Waktu & 1,174 & 0,587 & 0,795 & 0,74 & 0,514 & 1,01 \\
Suhu*Suhu & $-0,6$ & $-0,3$ & 1,05 & $-0,28$ & 0,796 & 1,08 \\
Waktu*Suhu & $-0,864$ & $-0,432$ & 0,512 & $-0,84$ & 0,461 & 1,05 \\
\hline
\end{tabular}

Bubuk kakao yang dihasilkan dari beberapa perlakuan pengepresan ini masih memiliki kadar air yang belum sesuai standar. Kandungan kadar air tersebut masih berada diatas batas minimum jika dibandingkan dengan kualitas bubuk kakao sesuai SNI, yaitu 5\%. Bahkan bubuk kakao yang dipres menggunakan suhu 130, 150 dan $170^{\circ} \mathrm{C}$ juga masih memiliki kadar air tinggi dan tidak sesuai SNI (Chatib, dkk., 2015). Ada beberapa faktor yang menyebabkan hal tersebut. Salah satunya adalah kualitas bahan baku biji kakao atau nib yang mengandung kadar air tinggi. Hal ini tentu saja cukup berbahaya karena tingginya kadar air pada bubuk kakao bisa menjadi media hidup bagi mikroorganisme. Dengan kata lain, kualitas produk akan menurun dan umur simpan bubuk kakao akan lebih singkat.

\section{Pengaruh Suhu dan Waktu Pengepresan Kakao terhadap rendemen Bubuk Kakao}

Hasil analisis model diperoleh nilai $\mathrm{R}^{2}$ sebesar $72,93 \%$, artinya waktu dan suhu pengepresan memberikan pengaruh sebesar 72,93\% terhadap rendemen bubuk kakao. Model yang disarankan adalah linear square dengan nilai Adj-R Square 45,87\%. Hal ini mengidentifikasikan bahwa model matematis memiliki signifikansi yang cukup rendah untuk dapat digunakan memprediksi rendemen bubuk kakao.

Tabel 7 menunjukkan hasil anova dan tabel 8 merupakan tabel koefisien terestimasi untuk rendemen bubuk kakao. Pada tabel 7 dapat dilihat bahwa model memiliki nilai f-value 2,69 dengan nilai $\mathrm{p}$ value 0,18 yang menunjukkan model tidak signifikan. Tabel tersebut menunjukkan bahwa waktu pengepresan $\left(X_{1}\right)$ tidak berpengaruh secara signifikan terhadap rendemen bubuk kakao karena nilai p-nya di diatas 0,05 . Tingkat suhu $\left(X_{2}\right)$ juga tidak berpengaruh secara signifikan terhadap kecerahan warna bubuk kakao karena nilai p-nya di atas 0,05. Hubungan kuadratik untuk waktu pengepresan $\left(X_{I}^{2}\right)$ menunjukkan hasil yang signifikan, yaitu 0,038 , sedangkan suhu pengepresan $\left(X_{2}^{2}\right)$ tidak signifikan dengan nilai 0,325. Pada Tabel 8 menunjukkan bahwa pada tabel tersebut terdapat persamaan regresi koefisien terestimasi yaitu dengan nilai awal intercept 62,85 .

Setelah dilakukan analisis sidik ragam dan diperoleh koefisien terestimasi, maka dapat diperoleh persamaan regresi untuk rendemen bubuk kakao:

Rendemen $(\mathrm{Y})=62,85-0,83 \mathrm{X}_{1}+1,17 \mathrm{X}_{2}$ 
Tabel 7. Anova untuk rendemen bubuk kakao

\begin{tabular}{lccccc}
\hline Source & DF & Adj SS & Adj MS & F-Value & P-Value \\
\hline Model & 4 & 184,444 & 46,111 & 2,69 & 0,18 \\
Linear & 2 & 12,333 & 6,167 & 0,36 & 0,718 \\
Waktu (X1) & 1 & 4,167 & 4,167 & 0,24 & 0,648 \\
Suhu (X2) & 1 & 8,167 & 8,167 & 0,48 & 0,528 \\
Square & 2 & 181,42 & 90,71 & 5,3 & 0,075 \\
Waktu*Waktu & 1 & 159,868 & 159,868 & 9,34 & 0,038 \\
Suhu*Suhu & 1 & 21,551 & 21,551 & 1,26 & 0,325 \\
Error & 4 & 68,444 & 17,111 & & \\
Total & 8 & 252,889 & & & \\
\hline
\end{tabular}

Tabel 8. Koefisien regresi terestimasi untuk rendemen bubuk kakao

\begin{tabular}{lcccccc}
\hline Term & Effect & Coef & SE Coef & T-Value & P-Value & VIF \\
\hline Constant & & 62,85 & 4,02 & 15,64 & 0 & \\
Waktu (X1) & $-1,67$ & $-0,83$ & 1,69 & $-0,49$ & 0,648 & 1,01 \\
Suhu (X2) & 2,33 & 1,17 & 1,69 & 0,69 & 0,528 & 1,08 \\
Waktu*Waktu & 18,75 & 9,38 & 3,07 & 3,06 & 0,038 & 1,01 \\
Suhu*Suhu & 9,11 & 4,56 & 4,06 & 1,12 & 0,325 & 1,08 \\
\hline
\end{tabular}

Hasil pengepresan dengan beberapa perlakuan menunjukkan nilai rendemen yang bervariasi. Rendemen paling tinggi diperoleh dengan suhu $70^{\circ} \mathrm{C}$ selama 30 menit, dan menurun pada suhu $100^{\circ} \mathrm{C}$. Menurut Indarti (2007), perlakuan suhu yang diberikan pada sekitar wadah pasta kakao saat proses pengepresan mampu meningkatkan rendemen sekitar 2 hingga $3 \%$. Perlakuan panas selama pengepresan dapat membuat lemak dalam pasta mencair dengan viskositas yang rendah sehingga lebih memudahkan lemak keluar. Namun demikian dari hasil analisis yang dilakukan, rendemen tidak meningkat secara signifikan pada suhu pemanasan $70^{\circ} \mathrm{C}, 80^{\circ} \mathrm{C}$ dan $90^{\circ} \mathrm{C}$.

Optimasi Suhu dan Waktu Pengepresan terhadap Kadar Air, Kadar Lemak, Kecerahan Warna dan Rendemen Bubuk Kakao

Hasil prediksi berdasarkan pengaruh suhu dan waktu pengepresan terhadap kecerahan warna (nilai L*) menujukkan titik optimal pada dengan suhu $70^{\circ} \mathrm{C}$ dengan waktu waktu 30,114 menit diperoleh kecerahan warna dengan satuan nilai $\mathrm{L}^{*}$ sebesar 50,7. Optimasi warna bubuk kakao ini mengacu pada bubuk kakao yang beredar dipasaran dengan merk Van Houten yang memiliki kecerahan warna dengan satuan nilai $\mathrm{L}^{*}$ sebesar 50,9. Hal ini sesuai dengan hasil analisis nilai $\mathrm{P}$ pada variabel suhu dan waktu terhadap kecerahan warna bubuk kakao kurang dari 0,05 sehingga memiliki pengaruh signifikan terhadap kecerahan warna optimal.

Prediksi solusi optimal yang diperoleh memiliki desirability value sebesar 0,83 $(83,2 \%)$. Nilai desirability menujukkan derajat ketepatan hasil solusi optimal, dimana semakin mendekati angka satu maka semakin tinggi nilai ketepatan optimal. Hasil optimasi juga diperkuat dengan nilai $\mathrm{R}^{2}$ pada gambar 2 yang menunjukkan perbandingan kecerahan warna prediksi dan observasi. Nilai $\mathrm{R}^{2}$ yang diperoleh sebesar 0,95 yang manujukkan bahwa hasil prediksi hampir mendekati observasi. 


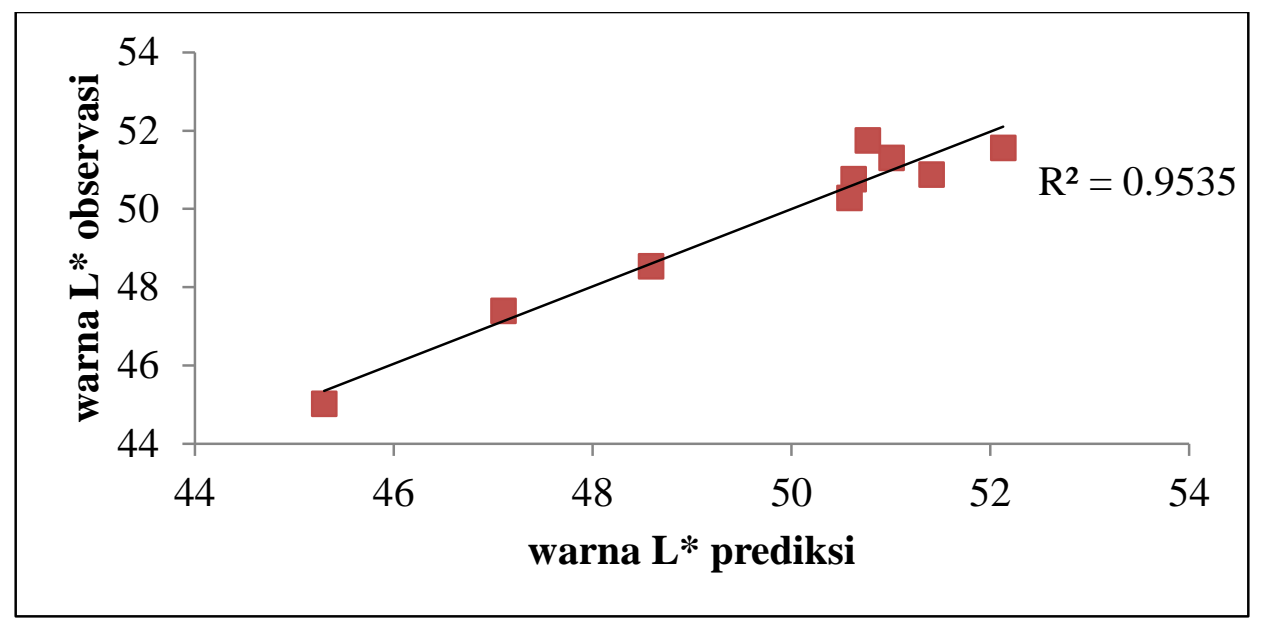

Gambar 1. Plot warna L* prediksi dengan warna L* observasi

Secara keseluruhan, bubuk kakao hasil pengepresan masih belum sesuai dengan SNI, khususnya untuk kadar air dan kadar lemak. Pada SNI Bubuk Kakao (2009) disyaratkan kadar air kurang dari 5\% dan kadar lemak minimal $10 \%$. Namun sebagian besar kadar air hasil pengepresan memiliki kadar air diatas 5\%, dan kadar lemak jauh diatas $10 \%$ atau berkisar $40-50 \%$. Hal ini tentu saja bisa mempengaruhi kualitas produk jika dipasarkan secara luas. Karena tingginya kadar lemak bisa rawan dengan ketengikan, sedangkan kadar air yang tinggi dapat mempengaruhi kelembaban dan rentan terhadap pertumbuhan mikrobia.

\section{KESIMPULAN}

1. Suhu dan Lama pengepresan mempengaruhi kecerahan warna bubuk kakao secara signifikan, namun tidak berpengaruh terhadap kadar air, kadar lemak, dan rendemen.

2. Proses pengepresan paling optimal dilakukan pada suhu $70^{\circ} \mathrm{C}$ dengan waktu 30,114 menit untuk memperoleh kecerahan warna bubuk kakao yang sesuai pasar.

\section{DAFTAR REFERENSI}

Aidoo, R.P., Afoakwa, E.O., \& Dewettinck, K. 2014. Optimization of inulin and polydextrose mixtures as sucrose replacers during sugar-free chocolate manufacture - $\quad$ Rheological, microstructure and physical quality characteristics. Journal of Food Engineering, 126: 35-42. DOI: 10.1016/j.jfoodeng.2013.10.036.

Chatib, O.C., Sandra, dan Asbani, H.M. (2015). Study of Equipment Presses of Cocoa Powder (Theobroma cacao, L) to Produce Quality Fat Cocoa and Analysis of the Resulting. International Journal on Advanced Science Engineernig Information Technology, 5 (6): 510-517.

Hanifah, R.N., Al Baarri, A.N., dan Pramono, Y.B. (2017). Determinasi Kadar Randemen, Tampilan Kecerahan, dan Kehijauan pada Bubuk Cincau Hijau (Premna oblongifolia) dengan Berbagai Variasi Suhu Pengeringan. Jurnal Teknologi Pangan, 1 (1): 25-27.

Indarti, E. (2007). Efek Pemanasan terhadap Rendemen Lemak pada Proses Pengepresan Biji Kakao. Jurnal Rekayasa Kimi dan Lingkungan, 6 (2): 50-54.

Junaidi, L., Sudibyo, A., Hutajulu, T.F., dan Abdurakhman, D. (2008). Pengaruh Perlakuan Suhu Ekstraksi terhadap Karakteristik Mutu Lemak Kakao. Journal of Agro-based Industry, 25 (2), 24-34.

Manulu, L.P., Djafar, M.Y., Wibawa, T.Y., dan Adinegoro, H. (2017). Proses Pintas Pengolahan Kakao Skala UKM 
Studi Kasus di Luwu Sulsel. Majalah Ilmiah Pengkajian Industri, 11 (1), 5160.

Mine, Gültekin-Özgüven, İjlal Berktaş, \& Beraat Özçelik. 2016. Influence of processing conditions on procyanidin profiles and antioxidant capacity of chocolates: Optimization of dark chocolate manufacturing by response surface methodology. Journal of Food Science and Technology, 66: 252-259.

DOI: 10.1016/j.lwt.2015.10.047.

Misnawi, Mulato, S., Widyotomo, S., Sewet, A., dan Sugiyono. (2005). Optimasi Suhu dan lama Penyangraian Biji Kakao Menggunakan Penyangrai Skala Kecil Tipe Silinder. Pelita Perkebunan, 21 (3): 169-183.

Mulato, S., Widyotomo, S., dan Nuraini, H. (2004). Kinerja Alat Penghalus Pasta Cokelat Tipe Silinder Berputar. Pelita Perkebunan, 20: 37-53.

Mulato, S., Widyotomo, S., Misnawi dan Suharyanto, E. (2005). Pengolahan Produk Primer dan Sekunder Kakao. Pusat Penelitian Kopi dan Kakao Indonesia, Jember.

Mulato, S., Widyotomo, S., dan Purwadaria, H.K. (2008). Kinerja Alat Kempa Hidrolik Sistem Terputus untuk Proses Ektraksi Lemak Kakao. Pelita Perkebunan, 24 (1), 62-79.

Permana, Mayun, I.D.G., Indriati, R., \& Hastuti, P. (2012). Optimasi Isolasi Lipase Indigenous Biji Kakao (Theobroma cacao L.). Jurnal Agritech, $32 \quad$ (1). $\quad$ DOI: 10.22146/agritech.9653.

Priyangini, F., Walde, S.G., \& Chidambaram, \& Ramalingam. (2018). Extraction optimization of pectin from cocoa pod husks (Theobroma cacao L.) with ascorbic acid using response surface methodology. Journal of Carbohydrate Polymers, 202: 497$503 . \quad$ DOI: 10.1016/j.carbpol.2018.08.103.

Rocha, I.S., Santana, L.R.R., Soares, S.E., \& Bispo, S.S. (2017). Effect of the roasting temperature and time of cocoa beans on the sensory characteristics and acceptability of chocolate. Journal of Food Science and Technology, 37 (4): 522-530.

SNI. (2009). SNI 3747 tentang Kakao Bubuk. Badan Standardisasi Nasional. Jakarta

Supriyanto dan Marseno, D.W. (2010). Penyangraian Hancuran Nib Kakao dengan Enerji Gelombang Mikro untuk Menghasilkan Cokelat Bubuk. Agritech, 30 (4): 243-249.

B.Shet, V., Nishasanil, Bhat, M., Naik, M., Mascarenhas, L.N., Goveas, L.C., Rao, C.V., Ujwal, P., Sandesh, K., Aparna, A. (2018). Acid hydrolysis optimization of cocoa pod shell using response surface methodology approach toward ethanol production. Journal of Agriculture and Natural Resources, 52: 581-587. DOI: 10.1016/j.anres.2018.11.022.

Widayat, H.P. (2013). Perbaikan Mutu Bubuk Kakao Melalui Proses Ekstraksi Lemak dan Alkalisasi. Jurnal Teknologi dan Industri Pertanian Indonesia, 5 (2): 12-16.

Widya, Alawiya. (2016). Optimasi Proses Ekstraksi Pektin dari Kulit Kakao (Theobroma cacao, L) Menggunakan Asam Sitrat dengan Variasi Suhu, pH Pelarut dan Lama Reaksi. Diploma thesis. UNIVERSITAS ANDALAS 